\title{
Ultra rare Paraplectana sakaguchii Uyemura, 1938 (Araneae: Araneidae) new to Korean spider fauna
}

\author{
Sue Yeon Lee ${ }^{1}$, Jung Sun $\mathrm{Yoo}^{2}$, Seung Tae Kim³,* \\ ${ }^{1}$ Research Institute for Agriculture and Life Sciences, Seoul National University, Seoul 151-921, Korea \\ ${ }^{2}$ Department of Exhibition and Education, National Institute of Biological Resources, Incheon 404-170, Korea \\ ${ }^{3}$ Life and Environment Research Institute, Konkuk University, Seoul 143-701, Korea \\ *Correspondent: stkim2000@hanmail.net
}

Paraplectana sakaguchii Uyemura, 1938 is a ultra rare species belonging to Araneidae worldwide. This species was collected by sweep net between the shrubs at the foot of mountainous region in August, 2012. This species is briefly described and illustrated in this report. The spider genus Paraplectana is also newly recorded to Korean spider fauna.

Keywords: Araneidae, description, Korea, Paraplectana sakaguchii

(C) 2015 National Institute of Biological Resources

DOI:10.12651/JSR.2015.4.1.057

\section{INTRODUCTION}

The spider genus Paraplectana comprises 11 species described mostly from Africa and Asia (Platnick, 2014); P. coccinella (Thorell, 1890) from Myanmar and Nias Is., P. duodecimmaculata Simon, 1897 from Java, $P$. hemisphaerica (C. L. Koch, 1844) from Sierra Leone, $P$. kittenbergeri Caporiacco, 1947 from Tanzania, P. multimaculata Thorell, 1899 from Cameroon and East Africa, $P$. sakaguchii Uyemura, 1938 from Japan and China, $P$. thorntoni (Blackwall, 1865) from Central Africa and Yemen, $P$. thorntoni occidentalis Strand, 1916 from West and Central, $P$. tsushimensis Yamaguchi, 1960 from China, Taiwan, and Japan, P. walleri (Blackwall, 1865) from West and Central Africa, and Madagascar, and $P$. walleri ashantensis Strand, 1907 from Ghana.

Among them, Paraplecta sakaguchii was erected by Uyemura in 1938 from Wakayama Prefecture, Japan. The male of this spider have never been described for $6 \mathrm{dec}-$ ades. In 2010, Tanikawa and Harigae (2010) finally described the male of this species. They secured the male of this species by hatching of unknown Cyrtarachnine eggsac obtained by chance. They identified the species by using morphological and molecular features. The single female of this species was collected by sweep net between the shrubs at the foot of Mt. Mudeung located in Gwangju metropolitan city in August, 2012. Present work briefly described and illustrated this species using a stereoscopic dissecting microscope (Olympus SZ 60). The spider genus Paraplectana is also newly recorded to Korean spider fauna. The voucher specimen of this study was deposited in the collection of National Institute of Biological resources (NIBR), Korea.

\section{Taxonomic Account}

\section{Paraplectana Brito Capello, 1867}

점박이새똥거미속 (신칭)

Paraplectana is very similar to Cyrtarachne in external feature. However, the genus Paraplectana can be easily distinguished from Cyrtarachne by muscle impressions and round patterns on abdominal dorsum (Uyemura, 1938).

Type species: Paraplectana thorntoni (Blackwall, 1865)

Paraplectana sakaguchii Uyemura, 1938 (Fig. 1A, B) 주황흰점박이새 똥거미 (신칭)

Paraplectana sakaguchii Uyemura, 1938: 90; Wang, Zhang and Li, 1985: 66; Chikuni, 1989: 83; Feng, 1990: 80; Yin et al., 1997: 385; Song, Zhu and Chen, 1999: 302; Tanikawa, 2007: 50; 2009: 428; Tanikawa and Harigae, 2010: 40.

Paraplectana quadrimamillata Schenkel, 1963: 177.

Description. Female: Body length about $7.20 \mathrm{~mm}$. Carapace longer than wide, reddish brown, fovea spiniform and distinct, cervical and radial grooves darker. Eight eyes 


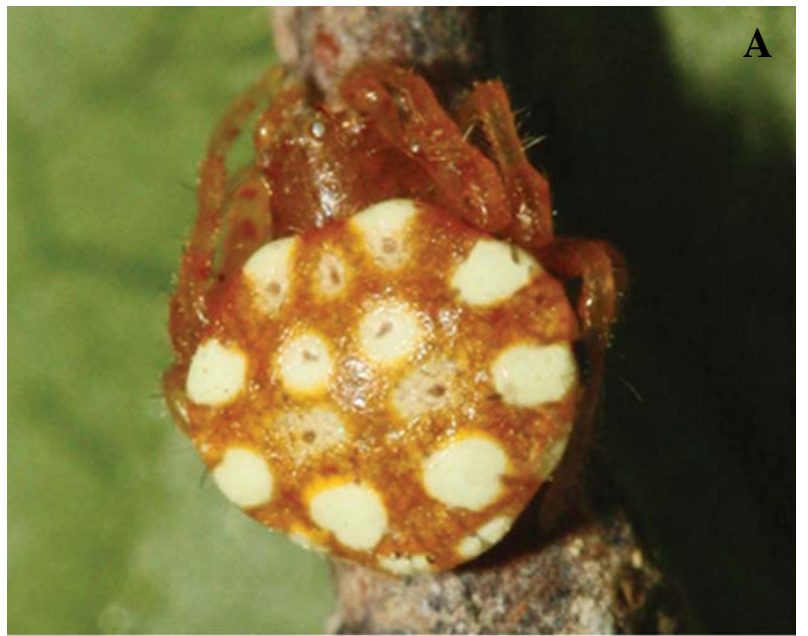

B

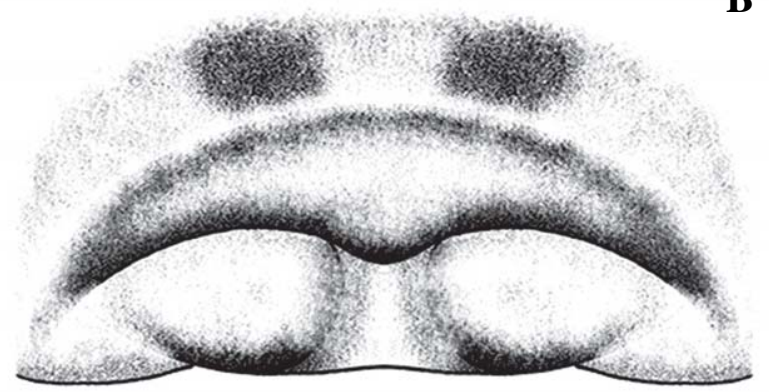

Fig. 1. Paraplectana sakaguchii Uyemura, 1938. A. female (ecological photo), B. female epigynum.

small, both eye rows slightly recurved from the above, anterior eye row slightly shorter than posterior eye row. Legs reddish brown and somewhat transparent, each segment with darker annulations. Abdomen round, reddish brown, subequal in length and width, 17 pale yellowish white markings on dorsum, 3 pairs of muscle impressions distinct (Fig. 1A). Female epigynum simple, atrium slightly sclerotized and swelled, median septum vestigial, no scape (Fig. 1B).

Specimen examined. 1 female, 05-VIII-2012, Mt. Mudeungsan, Gwangju metropolitan city, SY Lee and ST Kim leg.

Ecological remarks. This species collected with sweep net on the shrubs around the foot of mountainous region. This species also might be ultra rare in Korea, because the species was not collected despite intensive searching after first discover.

Distribution. Korea (newly recorded), China, Japan.

\section{ACKNOWLEDGEMENT}

This research was supported by National Institute of Biological Resources (The discovery of new and unrec- orded Korean indigenous species project 2013).

\section{REFERENCES}

Blackwall, J. 1865. Descriptions of recently discovered species and characters of a new genus, of Araneida from the East of Central Africa. Ann. Mag. nat. Hist. (3): 16:336352.

Brito Capello, F.de. 1867. Descripção de algunas especies novas ou pouco conhecidas de Crustaceo e Arachnidios de Portugal e possessoes portuguezas do Ultramar. Mem. Acad. sci. Lisboa (N.S.) 4(1):1-17.

Caporiacco, L.di. 1947. Arachnida Africae Orientalis, a dominibus Kittenberger, Kovács et Bornemisza lecta, in Museo Nationali Hungarico servata. Annls hist.-nat. Mus. natn. hung. 40:97-257.

Chikuni, Y. 1989. Pictorial Encyclopedia of Spiders in Japan. Kaisei-sha Publ. Co., Tokyo, 310 pp.

Feng, Z.Q. 1990. Spiders of China in colour. Hunan Science and Technology Publishing House, $256 \mathrm{pp}$.

Koch, C.L. 1844. Die Arachniden. Nürnberg, Eilfter Band, pp. 1-174.

Platnick, N.I. 2015. The world spider catalog, version 15. American Museum of Natural History, [Available from: http://research.amnh.org/entomology/spiders/catalog/ind ex.html DOI: 10.5531/db.iz.0001].

Schenkel, E. 1963. Ostasiatische Spinnen aus dem Muséum d'Histoire naturelle de Paris. Mém. Mus. natn. Hist. nat. Paris (A, Zool.) 25:1-481.

Simon, E. 1897. Etudes arachnologiques. 27e Mémoire. XLII. Descriptions d'espèces nouvelles de l'ordre des Araneae. Ann. Soc. ent. Fr. 65:465-510.

Song, D.X., M.S. Zhu and J. Chen. 1999. The Spiders of China. Hebei Sci. Technol. Publ. House, Shijiazhuang, 640 pp.

Strand, E. 1907. Afrikanische Spinnen (exkl. Aviculariiden) hauptsächlich aus dem Kapland. Zool. Jahrb. Syst. 25: 557-731.

Strand, E. 1916. Zehn neue äthiopische Lycosiden nebst Bemerkungen über einige weitere exotische Araneae. Jahrb. nassau. Ver. Naturk. 69:97-118.

Tanikawa, A. 2007. An identification guide to the Japanese spiders of the families Araneidae, Nephilidae and Tetragnathidae. Arachnological Society of Japan, $121 \mathrm{pp}$.

Tanikawa, A. and T. Harigae. 2010. The first description of a male of Paraplectana sakaguchii (Araneae: Araneidae). Acta arachn. Tokyo 59:39-41.

Thorell, T. 1890. Aracnidi di Nias e di Sumatra raccolti nel 1886 dal Sig. E. Modigliani. Ann. Mus. civ. stor. nat. Genova 30:5-106.

Thorell, T. 1899. Araneae Camerunenses (Africae occidentalis) quas anno 1891 collegerunt Cel. Dr Y. Sjöstedt aliique. Bih. Svenska. Vet.-Akad. Handl. 25(1):1-105. 
Uyemura, T. 1938. Two new spiders from Wakayama Prefecture, Japan. Acta arachn. Tokyo 3:90-95.

Wang, J.F., Y.J. Zhang and F.J. Li. 1985. New report of some spiders from southern China. J. Hunan Normal Univ. 1985(2):66-69.

Yamaguchi, T. 1960. A new species of genus Paraplectana from Tsushima, Japan. Sci. Bull. Fac. lib. Arts Educ., Nagasaki Univ. 11:5-7.
Yin, C.M., J.F. Wang, M.S. Zhu, L.P. Xie, X.J. Peng and Y.H. Bao. 1997. Fauna Sinica: Arachnida: Araneae: Araneidae. Science Press, Beijing, xiii+460 pp.

Submitted: January 16, 2015 Revised: February 13, 2015 Accepted: February 25, 2015 